\title{
HABEAS CORPUS, CIVIL RIGHTS, AND THE FEDERAL SYSTEM
}

\author{
O. John Rogge and MURray A. Gordon $\dagger$
}

I

$\mathrm{F}$ IINAIITY AND JUSTICE are frequently incompatible. Finality forecloses that further inquiry which might reveal injustice. Yet institutions which define and enforce rights must conclude investigation if such rights are ever to be fixed. If error is committed in the process, that is part of the price of effective institutional action. In the judicial system, the appeal and motion for a new trial are the orthodox post-decision methods for the further search for justice; once these have been employed and no error found, the case is usually at an end. If error there be, short of perpetration of fraud upon the court, it is beyond the judicial ken.

But where the judicial action involves human liberty, a different balance between finality and justice must be struck. Any system premised upon the individual as the ultimate value cannot tolerate the erroneous or unjust deprivation of life or liberty to satisfy some institutional expediency. The great and ancient writ of habeas corpus is the last-resort writ which serves this purpose. "Without limit of time," this writ "comes in from the outside," after the regular process of judgment is at an end, to measure and test whether the loss of life or liberty directed by judgment is proper. The prior judgment is, of course, not forgotten; the principle of finality has a place in the criminal law. But the essence of habeas corpus derives from the circumstance that while the prior judgment is entitled to great weight, it is not conclusive. ${ }^{3}$ Habeas corpus acts thus as the accommodation of the interests of finality and justice in the criminal law. ${ }^{4}$

Lines of accommodation are usually shady, especially where the opposing

$\dagger$ The authors, members of the New York Bar, are counsel for petitioners in Daniels v. Allen, which was reargued before the Supreme Court on October 13, 1952. See Postscript, p. 525 supra, for a discussion of the Court's decision, handed down after this article was in galleys.

1 United States v. Smith, 331 U.S. 469, 475 (1947).

2 Darr v. Burford, 339 U.S. 200, 233 (1950); see also Holmes, J., dissenting, in Frank v. Mangum, 237 U.S. 309, 345, 346 (1915).

${ }^{3}$ Waley v. Johnston, 316 U.S. 101 (1942); Wong Doo v. United States, 265 U.S. 239 (1924); Salinger v. Loisel, 265 U.S. 224 (1924); Frank v. Mangum, 237 U.S. 309 (1915); Dorsey v. Gill, 148 F. 2d 857, 869 (App. D.C., 1945), cert. denied, 325 U.S. 890 (1945); Parker, Limiting the Abuse of Habeas Corpus, 8 F.R.D. 171 (1948).

${ }^{4}$ See Dorsey v. Gill, 148 F. 2d 857 (App. D.C., 1945), cert. denied, 325 U.S. 890 (1945), for an excellent discussion of the considerations underlying federal habeas corpus. See also Parker, op. cit. supra note 3 , at 172. 
thrusts are as powerful as finality and justice. When the jurisdiction of the federal courts is invoked to review by habeas corpus the detention of a prisoner convicted by state court process, the delicate adjustment required wherever the federal judiciary is importuned to supervise the judiciary of a sovereign state is superimposed upon and complicates further the finality-justice interplay. It is not surprising that definition of the scope and function of federal habeas corpus has been confused-although, by the same token, it has been flexible. ${ }^{6}$ Indeed, in our view the adaptability of the writ-the proper prime quality of "the freedom writ" -is the main component of its definition.

The writ of habeas corpus, the origins of which the scholars find obscure, ${ }^{8}$ was part of the English common-law judicial machinery received by this country. ${ }^{9}$ At the time of its reception, its function, with respect to testing the propriety of official detention, was limited largely to a review of the record for the purpose of ascertaining whether "the prisoner was held under final process based upon a judgment or decree of a court of competent jurisdiction."10 Federal habeas corpus to review the detention of persons in state custody was even more limited. "No writ of habeas corpus, except ad testificandum, could be issued in the case of a prisoner in jail under commitment by a court or magistrate of a State."11 By statute, this federal habeas corpus jurisdiction over state action was slightly enlarged prior to $1867 . .^{12}$ Then in 1867 , as a consequence of the Civil War, legislation was adopted ${ }^{13}$ authorizing the federal courts to grant the writ in the instance of a prisoner in state custody "in violation of the Constitution or of a law or treaty of the United States."14

' Toucey v. New York Life Ins. Co., 314 U.S. 118, 129-41 (1941); Taylor and Willis, The Power of Federal Courts to Enjoin Proceedings in State Courts, 42 Yale L.J. 1169 (1933); Warren, Federal and State Court Interference, 43 Harv. L. Rev. 345 (1930).

- See Price v. Johnston, 334 U.S. 266, 283 (1948); Adams v. United States ex rel. McCann, 317 U.S. 269, 274 (1942).

${ }^{7}$ The Freedom Writ-The Expanding Use of Federal Habeas Corpus, 61 Harv. L. Rev. 657 (1948). See also Bowen v. Johnston, 306 U.S. 19, 26 (1939).

${ }^{8}$ Moore's Commentary on the United States Judicial Code 417 (1949); Longsdorf, Habeas Corpus: A Protean Writ and Remedy, 8 F.R.D. 179 (1948); Dobie, Habeas Corpus in the Federal Courts, 13 Va. L. Rev. 433 (1927); 61 Harv. L. Rev. 657 (1948).

9 McNally v. Hill, 293 U.S. 131, 136 (1934); Moore, op. cit. supra note 8, at 417-19.

10 Frank v. Mangum, 237 U.S. 309, 330 (1915).

11 Whitten v. Tomlinson, 160 U.S. 231, 239 (1895).

124 Stat. 634 (1833); 5 Stat. 539 (1842).

1314 Stat. 385 , c. 28 (1867), as amended, 62 Stat. 964 (1948), 28 U.S.C.A. $\$ \$ 2241-55$ (1950).

1114 Stat. 385 , c. 28 (1867), as amended, 28 U.S.C.A. \$2241(c)(3) (1950). It has been aptly remarked that the statute, "designed to enforce the Reconstruction Acts and to effectuate the war-won liberty of all persons, made two drastic changes in federal habeas corpus. The writ would now be granted for any detention in violation of the Constitution or laws of the United States. In addition to this change in substantive grounds, federal habeas corpus, when invoked on such grounds, was made available to all persons whether in state or federal custody. The Fourteenth Amendment, by assuring freedom from improper state processes, increased the constitutional rights enforceable by habeas corpus." 61 Harv. L. Rev. 657, 659 (1948). 
Notwithstanding the expansive federal jurisdiction granted and intended in the act of 1867, the Supreme Court continued for some time to regard that jurisdiction as limited to a test of jurisdiction over the subject matter ${ }^{15}$ On occasion, however, even in the earlier cases, "jurisdictional" requirements were equated with constitutional mandates and prohibitions for purposes of federal habeas corpus, so that in In re Nielsen ${ }^{16}$ the Supreme Court described habeas corpus jurisdiction by reference to the "express provision of the Constitution, which bounds and limits all jurisdiction."17 And on other occasions the writ was allowed upon a showing of violation of rights more properly deriving from the Constitution than from any jurisdictional excess. ${ }^{18}$ But so long as review of state court convictions by writ of error to the United States Supreme Court remained a matter of right, ${ }^{19}$ the pressure for an extended federal habeas corpus jurisdiction was not great. That pressure was further subordinated to considerations of comity and deference owing to the state courts, which dictated that, as a matter of discretion, only the highest court in the federal judicial system should exercise the power to reverse the action of a state court. ${ }^{20}$

With the transition from review by the United States Supreme Court as a matter of right to review as a matter of discretion effected by the Judiciary Acts of $1916^{21}$ and $1925,{ }^{22}$ the pressure for expanding federal habeas corpus review of federal questions raised upon state prosecutions became more exigent. If the old channel of federal review became clogged till it allowed but a trickle, other routes had to be, and were, found to handle the surge of persons detained under state convictions asserting violation of federal constitutional rights. And that surge became even more urgent as the rights guaranteed under the Fourteenth Amendment to the United States Constitution received the expansive definition of the last thirty years. ${ }^{23}$ Judicial revision of the scope of federal

${ }^{15}$ See, e.g., Goto v. Lane, 265 U.S. 393, 402 (1924); Felts v. Murphy, 201 U.S. 123 (1906); Valentina v. Mercer, 201 U.S. 131 (1906); Crossley v. California, 168 U.S. 640 (1898); Bergemann v. Backer, 157 U.S. 655 (1895); Kohl v. Lehlback, 160 U.S. 293 (1895).

16131 U.S. 176 (1889).

17 Ibid., at 185. See also Rogers v. Peck, 199 U.S. 425, 434 (1905); Ex parte Wilson, 114 U.S. 417, 422 (1885); Ex parte Yarbrough, 110 U.S. 651, 654 (1884); Ex parte Siebold, 100 U.S. 371, 376, 377 (1879); The Writ of Habeas Corpus in the Federal Courts, 35 Col. L. Rev. $404,406,411$ (1935).

${ }_{18}$ Minnesota v. Barber, 136 U.S. 313 (1890); In re Nielsen, 131 U.S. 176 (1889); Ex parte Bain, 121 U.S. 1 (1887); In re Snow, 120 U.S. 274 (1887); Ex parte Siebold, 100 U.S. 371, 376, 377 (1879); Ex parte Green, 114 Fed. 959 (C.C. Ky., 1902).

19 Judiciary Act of 1789, 1 Stat. 85 (1789).

20 Mratter of Spencer, 228 U.S. 652 (1913); Urquhart v. Brown, 205 U.S. 179 (1907); Markuson v. Boucher, 175 U.S. 184 (1899); Baker v. Grice, 169 U.S. 284 (1898); Andrews v. Swartz, 156 U.S. 272 (1895); In re Wood, 140 U.S. 278 (1891); Ex parte Royall, 117 U.S. 241 (1886).

2139 Stat. 726 (1916), repealed, 62 Stat. 992 (1948).

2243 Stat. 936 (1925), repealed, 62 Stat. 992 (1948).

23 "The use of the Fourteenth Amendment in protecting individuals against arbitrary or unfair procedures in the state courts has been a development dating almost entirely from the late 1920's." Emerson \& Haber, Political and Civil Rights in the United States viii (1952). See also ibid., c. II, for cases and other materials setting out that development. 
habeas corpus jurisdiction reflected and met these pressures..$^{24}$ The test shifted perceptively from a review of "jurisdiction" to an inquiry whether fundamental constitutional rights had been abridged ${ }^{25}$-from the gloss on the act of 1867 to the express language of the act:

Habeas corpus is presently available for use by a district court within its recognized jurisdiction whenever necessary to prevent an unjust and illegal deprivation of human liberty. ${ }^{26}$

... the federal courts will entertain habeas corpus to redress the violation of [a] federal constitutional right. ${ }^{27}$

... the use of the writ in the federal courts to test the constitutional validity of a conviction for crime is not restricted to those cases where the judgment of conviction is void for want of jurisdiction of the trial court to render it. It extends also to those exceptional cases where the conviction has been in disregard of the constitutional rights of the accused. ... ${ }^{28}$

... if it be found that the court had no jurisdiction to try the petitioner, or that in its proceedings his constitutional rights have been denied, the remedy of habeas corpus is available..$^{29}$

And to assure that the writ's probe for serious constitutional error was complete, the Court, beginning with Frank v. Mangum, ${ }^{30}$ provided that the area of inquiry extended beyond and behind the state record so "the very truth," "the very tissue of the structure,"32 would be disclosed. ${ }^{33}$

\section{II}

The pantheon of federal constitutional rights capable of being safeguarded by federal habeas corpus against state action is now probably correlative with the equal protection and due process clauses of the Fourteenth Amendment. In Hawk v. Olson, ${ }^{34}$ the Supreme Court set out in some detail the situations which

24 The Freedom Writ, op. cit. supra note 7, at 659-61.

25 Various commentators have noted the foregoing shift from the so-called "jurisdictional" test to the so-called "fundamental constitutional rights" test. Moore, op. cit. supra note 8, at 419-22; McGraw and Stewart, Limitations on Habeas Corpus in the Federal District Courts, 26 Notre Dame Lawyer 487, 488 (1951); Peters, Collateral Attack by Habeas Corpus upon Federal Judgments in Criminal Cases, 23 Wash. L. Rev. 87, 89 (1948); The Freedom Writ, op. cit. supra note 7, at 661; The Writ of Habeas Corpus in the Federal Courts, op. cit. supra note 17. See also Smith v. United States, 187 F. 2d 192, 195 (App. D.C., 1950), cert. denied, 341 U.S. 927 (1951); United States ex rel. Innes v. Hiatt, 141 F. 2d 664, 665 (C.A. $3 d, 1944)$.

${ }^{26}$ Wade v. Mayo, 334 U.S. 672, 681 (1948).

${ }^{27}$ Hawk v. Olson, 326 U.S. 271, 276 (1945).

${ }^{23}$ Waley v. Johnston, 316 U.S. 101, 104-5 (1942).

29 Bowen v. Johnston, 306 U.S. 19, 24 (1939).

${ }^{30} 237$ U.S. 309 (1915). 31 Ibid., at 331.

${ }^{2}$ Ibid., at 346 (Holmes, J., dissenting).

${ }^{33}$ See also Carter v. Illinois, 329 U.S. 173 (1946); Hawk v.Olson, 326 U.S. 271 (1945); Waley v. Johnston, 316 U.S. 101 (1942); Holiday v. Johnston, 313 U.S. 342 (1941); Walker v. Johnston, 312 U.S. 275 (1941); Johnson v. Zerbst, 304 U.S. 458 (1938); Holtzoff, Collateral Review of Convictions in Federal Courts, 25 B.U. L. Rev. 26, 32-33 (1945).

34326 U.S. 271 (1945). 
up to the date of that decision, 1945, would authorize the issuance of the federal writ:

This liberalization of habeas corpus required Federal courts, when the issue was presented, to examine whether a conviction occurred under such influence by mob spirit as to deny due process. Frank 0 . Mangum, supra. The power was called into play a few years later to examine a state conviction under alleged community coercion and this Court said that if the facts set out were true, the trial would not support a conviction. Moore v. Dempsey, 261 U.S. 86. In Mooney v. Holohan, 294 U.S. 103, 112, it was declared that the knowing use of material perjured testimony by a state prosecutor would make a trial unfair within the meaning of the Fourteenth Amendment.

When the absence of counsel at a trial was urged as a ground for a Federal writ of habeas corpus, we held that in Federal courts a felony conviction without benefit of counsel is subject to collateral attack because a violation of the accused's constitutional right to the services of an attorney unless he has intelligently waived that privilege. Jolnson v. Zerbst, supra; Walker v. Jolnston, 312 U.S. 275, 286. The same is true in instances of coercion. Waley v. Johnston, 316 U.S. $101,104$.

In state prosecutions a conviction on a plea of guilty, obtained by a trick, Smith $v$. O'Grady, 312 U.S. 329, 334, or, after refusal of a proper request for counsel, because of the accused's incapacity adequately to defend himself, Williams v. Kaiser, 323 U.S. 471,472 , will not support imprisonment. Such procedure violates the Fourteenth Amendment to the Constitution. See Tomkins v. Missouri, 323 U.S. 485; Cochran v. Kansas, 316 U.S. 255. That Amendment is violated also when a defendant is forced by a state to trial in such a way as to deprive him of the effective assistance of counsel. Powell v. Alabama, supra; House v. Mayo, 324 U.S. 42. Compare Ex parte Hawk, 321 U.S. 114, Glasser ग. United States, 315 U.S. 60, 69, 70.35

Clearly the categories of federal habeas corpus action thus formulated were not intended to be frozen. Inquiry is therefore appropriate concerning two Fourteenth Amendment questions frequently arising out of state prosecutionsthe use of coerced confessions and the exclusion of Negroes from juries ${ }^{36}$-which were not referred to by the Court in Hawk v. Olson.

Prior to the Judiciary Act of 1925, the Court had held the question of exclusion of Negroes from state court juries unreviewable by federal habeas corpus. $^{37}$ And various lower federal courts held similarly when state prisoners

${ }^{35}$ Ibid., at 275-76. The discriminatory denial of a statutory right of appeal is another basis for federal habeas corpus review of a state conviction. Dowd v. United States ex rel. Cook, 340 U.S. 206, 208 (1951); Cochran v. Kansas, 316 U.S. 255 (1942).

${ }^{36}$ The issue of the availability of federal habeas corpus to review state convictions tainted by coerced confessions or exclusions of Negroes from juries is presently pending before the Supreme Court for decision. Daniels v. Crawford, 99 F. Supp. 208 (D.C. N.C., 1951), aff'd sub nom. Daniels v. Allen, 192 F. 2 d 763 (C.A. 4th, 1951), cert. granted, 342 U.S. 941 (1952), reargument ordered, 343 U.S. 973 (1952); Speller v. Crawford, 99 F. Supp. 92 (D.C. N.C., 1951), aff'd sub nom. Speller v. Allen, 192 F. 2 d 477 (C.A. 4th, 1951), cert. granted, 342 U.S. 953 (1952), reargument ordered, 343 U.S. 973 (1952); Brown v. Allen, 192 F. 2 d 477 (C.A. 4th, 1951), cert. granted, 343 U.S. 903 (1952), reargument ordered, 343 U.S. 973 (1952).

${ }^{37}$ Andrews v. Swartz, 156 U.S. 272 (1895); In re Wood, 140 U.S. 278 (1891). See also Kaizo v. Henry, 211 U.S. 146 (1908).

In appraising these and other cases decided prior to the Judiciary Acts of 1919 and 1925, which refused habeas corpus and relegated the applicant to his writ of error, it must be re- 
challenged their convictions on the ground that their involuntary confession had been admitted in evidence against them..$^{38}$ But the development of federal habeas corpus jurisdiction occasioned by the Judiciary Act of 1925 and the recent decisional enlargement of the due process and equal protection clauses affect the authority of those earlier cases.

That the admission into evidence of coerced confessions may be violative of fundamental constitutional rights safeguarded by federal habeas corpus was indicated by the United States Supreme Court in the last Term. In Jennings v. Illinois ${ }^{39}$ applicants for federal habeas corpus complained that their convictions in the state courts were the result of involuntary confessions. In writing for the Court, Vinson, C. J., said:

If their allegations are true and if their claims have not been waived at or after trial, petitioners are held in custody in violation of federal constitutional rights. Petitioners are entitled to their day in court for the resolution of these issues. Where the state does not afford a remedy, a state prisoner may apply for a writ of habeas corpus in the United States District Court to secure protection of his federal rights. ${ }^{40}$

This determination was foreshadowed by many earlier decisions. It had been settled that federal habeas corpus jurisdiction extended to state prosecutions wherein perjured testimony was knowingly employed by the prosecution in order to obtain a conviction. If If the writ will issue for the use of coerced or perjured testimony of one other than the accused, the writ should issue to remedy the use of coerced and perjured testimony of the accused. ${ }^{42}$ Similarly, a plea of guilty induced by intimidation is properly the subject of attack by habeas corpus. ${ }^{43}$ The analogous vulnerability of a coerced confession was pointed out by the Supreme Court:

membered that from 1789 to 1872 , the time to sue out a writ of error to the United States Supreme Court from a state court was five years from date of judgment [see, e.g., Brooks v. Norris, 11 How. (U.S.) 203 (1851)]; and from the Act of June 1, 1872, 17 Stat. 196 (1872), to the Act of September 6, 1916, 39 Stat. 726 (1916), the time period was two years. Allen v. Southern Pac. R. Co., 173 U.S. 479 (1899); Cummings v. Jones, 104 U.S. 419 (1881). For this reason, it appeared clearly in some of the earlier cases that when the Court denied the writ of habeas corpus, time still remained to proceed by writ of error. Urquhart v. Brown, 205 U.S. 179, 183 (1907); Markuson v. Boucher, 175 U.S. 184, 187 (1899). See also Reid v. Jones, 187 U.S. 153 (1902); Tinsley v. Anderson, 171 U.S. 101 (1898).

${ }^{38}$ Smith v. United States, 187 F. 2 d 192 (App. D.C., 1950), cert. denied, 341 U.S. 927 (1951); Schramm v. Brady, 129 F. 2d 108 (C.A. 4th, 1942). See also Collins v. McDonald, 258 U.S. 416 (1922); Harlan v. McGourin, 218 U.S. 442 (1910).

${ }^{39} 342$ U.S. 104 (1951).

${ }^{40} \mathrm{Ibid}$., at 110,111 . Without referring to Jennings $\mathrm{v}$. Illinois, or any of the authorities cited note 38 supra, the Third Circuit Court of Appeals recently held that federal habeas corpus would issue upon a showing of the admission into evidence of a coerced confession into a state prosecution. United States ex rel. Master v. Baldi, 198 F. 2d 113 (C.A. 3d, 1952).

41 Burke v. Georgia, 338 U.S. 941 (1950); Hawk v. Olson, 326 U.S. 271, 275 (1945); Pyle v. Kansas, 317 U.S. 213 (1942); Mooney v. Holohan, 294 U.S. 103 (1935).

42 Hysler v. Florida, 315 U.S. 411, 413 (1942); Lisenba v. California, 314 U.S. 219, 237 (1941); Moore, op. cit. supra note 8, at 421 n. 19; Peters, op. cit. supra note 25, at 99-100.

${ }^{43}$ Von Moltke v. Gillies, 332 U.S. 708 (1948); Waley v. Johnston, 316 U.S. 101 (1942). 
For a conviction on a plea of guilty coerced by a federal law enforcement officer is no more consistent with due process than a conviction supported by a coerced confession. 44

Moreover, the Court has in numerous instances, albeit not habeas corpus proceedings, expressed in strong language the view that infliction of punishment upon the basis of an involuntary confession violated elementary notions of justice and fair play which are of constitutional stature. ${ }^{45} \mathrm{It}$ would seem, therefore, that relief by habeas corpus must be justified under such circumstances.

A judgment rendered by a jury from which has been excluded competent and qualified persons solely for reasons of race or color should also be considered the proper subject of inquiry upon federal habeas corpus. The composition of the grand and petit juries are matters which literally go to "jurisdiction." One commentator has therefore concluded with respect to the right to challenge juries from which Negroes have been excluded:

If the defendant did not waive his right by failing to assert it at his trial, then it would always be available to him even by a later application for a writ of habeas corpus. ${ }^{46}$

This conclusion is warranted by the decisions of the Supreme Court which hold that the denial to a Negro defendant "of his right to a selection of grand and petit jurors without discrimination against his race, because of their race, would be a violation of the Constitution and the laws of the United States." In fact, error of this character has been said to be "at war with our basic concepts of a democratic society and a representative government." 48 Racial discrimination in the selection of jurors would appear to raise a constitutional infurmity of the basic and fundamental kind required as a predicate for habeas corpus relief.

Various lower federal courts have assumed that, if properly raised and preserved, error in the exclusion of Negroes from juries in a state prosecution would

44 Waley v. Johnston, 316 U.S. 101, 104 (1942).

45 The introduction into evidence of a confession elicited by physical or mental duress has been characterized as violative of "fundamental notions of fairness and justice." Haley v. Ohio, 332 U.S. 596, 607 (1948). Similarly, such confessions were deemed to run afoul of "those canons of decency and faimess which express the notions of justice of English-speaking peoples even towards those charged with the most heinous offenses." Malinski v. New York, 324 U.S. 401,417 (1945). The Court has gone so far as to hold that a conviction resulting from the use of a coerced confession is "void." Lee v. Mississippi, 332 U.S. 742, 745 (1948). And in the earliest and most authoritative case on the subject, Brown v. Mississippi, 297 U.S. 278 (1936), Chief Justice Hughes wrote of a conviction based upon an involuntary confession that "the conviction and sentence were void for want of the essential elements of due process, and the proceeding thus vitiated could be challenged in any appropriate manner. ..." Ibid., at 287.

${ }^{46}$ Peters, op. cit. supra note 25 , at 93.

17 Hill v. Texas, 316 U.S. 400, 406 (1942); Pierre v. Louisiana, 306 U.S. 354, 361 (1939); Hale v. Kentucky, 303 U.S. 613, 616 (1938); Norris v. Alabama, 294 U.S. 587, 589 (1935); Bush v. Kentucky, 107 U.S. 110, 119 (1882); Neal v. Delaware, 103 U.S. 370, 394 (1880); Virginia v. Rives, 100 U.S. 313, 322, 323 (1879).

${ }^{18}$ Smith v. Texas, 311 U.S. 128, 130 (1940). 
be a matter for review in the federal courts by habeas corpus. ${ }^{49}$ The Court of Appeals for the First Circuit addressed itself precisely to the effect that the change in the nature of the Supreme Court's jurisdiction after the Judiciary Act of 1925 had upon the right of a defendant in a state prosecution to challenge in federal habeas corpus the exclusion of Negroes from the trial jury:

Counsel for Crawford [petitioner] contend that these cases are not applicable for, if he were remitted to Virginia and seasonably and properly raised the question here under consideration and the question was decided against him, at the present time and under the Judiciary Act of 1925, he could not, as of right, prosecute a writ of error from the Supreme Court of the United States to the highest court of Virginia to which the case could be taken. It is true that his right of review by writ of error from the Supreme Court of the United States on the facts of this case was taken away by the act of 1925, for under the law as it now stands no writ of error lies from the Supreme Court in this case, as the grand jury was not drawn under a statute of the state of Virginia which violated the Constitution of the United States. 43 Stat. 936, 937, c. 229, $\S 237$ (28 U.S.C.A. $\$ 344$ ). He is, however, permitted by that act to apply to that court for certiorari, a discretionary writ. South Carolina v. Bailey, supra. If review on such application is not granted he undoubtedly, at that state of the proceedings, could have the matter reviewed on habeas corpus in the proper federal court, being without review in the Supreme Court on writ of error as of right. In re Royall, pages 289,290 . It would not then be an endeavor by habeas corpus to intervene before trial or to review what ordinarily can be re-examined only on writ of error; and the federal court applied to could not, under such circumstances, properly refuse review on habeas corpus..$^{50}$

\section{III}

The story of modern federal habeas corpus jurisdiction is, however, concerned less with the question of what matters are reviewable than with the question of when such review may be invoked. The desire to preserve state court judgments from federal disturbance has inspired the development of a formidable and variegated set of requirements to be met by the state prisoner who would venture into a federal court for relief. If the state prisoner insists upon carrying his conviction to the federal courts he may do so only upon hur-

${ }^{49}$ Johnson v. Sanford, 167 F. 2d 738 (C.A. 5th, 1948); United States ex rel. Jackson v. Brady, 133 F. 2 d 476 (C.A. 4th, 1943), cert. denied, 319 U.S. 746 (1943); Johnson v. Wilson, 131 F. 2d 1 (C.A. 5th, 1942); Carruthers v. Reed, 102 F. 2 d 933 (C.A. 8th, 1939), cert. denied, 307 U.S. 643 (1939).

${ }^{50}$ Hale v. Crawford, 65 F. $2 d$ 739, 749 (C.A. 1st, 1933). The relationship between a fair trial and a jury selected without regard to the race or color of its members is clear. The community which will foreclose the Negro from exercising his rights and prerogatives as a citizen to sit as a juror will exercise less than calm, dispassionate, and fair judgment of a Negro charged with a crime. Judgment by such a jury, the selection of which caters to, and reflects, racial discrimination against Negroes, would be a judgment predicated upon factors unrelated to the innocence or guilt of the accused; a jury which mirrors the community pattern of racial discrimination would be incapable of fair and unbiased judgment. However scrupulous the observance of the regular forms of the trial process, the trial could not be the fair trial of the issue of the innocence or guilt of the accused which is inherent in our notion of elementary justice. 
dling every procedural barrier which ingenuity born of a reverence for states' rights can devise.

$\S 2254$ of Title 28 of the Code, the governing statute, is intended to codify the pre-existent law and provides:

An application for a writ of habeas corpus in behalf of a person in custody pursuant to the judgment of a State court shall not be granted unless it appears that the applicant has exhausted the remedies available in the courts of the State, or that there is either an absence of available State corrective process or the existence of circumstances rendering such process ineffective to protect the rights of the prisoner.

An applicant shall not be deemed to have exhausted the remedies available in the courts of the State, within the meaning of this section, if he had the right under the law of the State to raise, by any available procedure, the question presented. ${ }^{51}$

How $\S 2254$ in action can mouse-trap the applicant has been noted by several commentators. ${ }^{52}$ The Supreme Court has, in Darr v. Burford, ${ }^{53}$ held that a petition to the Supreme Court to review the state conviction by certiorari is part of

\$1 Daniels v. Crawford, 99 F. Supp. 208 (D.C. N.C., 1951), aff'd sub nom. Daniels v. Allen, 192 F. 2d 763 (C.A. 4th, 1951), cert. granted, 342 U.S. 941 (1952), reargument ordered 343 U.S. 973 (1952), presently pending for decision by the Supreme Court, raises the question whether the requirement that the applicant exhaust "remedies available" extends to remedies once, but no longer, available because of the expiration of the time limit within which such remedies must be sought. It has never been expressly decided, heretofore, by the Court whether in such circumstances, absent a clear waiver, federal habeas corpus is proper to review fundamental constitutional questions when no state remedy is any longer available. See Exhaustion of State Remedies as a Condition for Federal Habeas Corpus, 34 Minn. I. Rev. 653, 658 (1950); The Freedom Writ, op. cit. supra note 7, at 666; Habeas CorpusExhaustion of Alternative Remedies, 40 Col. L. Rev. 535, 537 (1940). See also 37 Cornell L.Q. 296, 297 (1952), noting Collins v. Frisbie, 189 F. 2d 464 (C.A. 6th, 1951). The question was raised, but not passed upon, in Wade v. Mayo, 334 U.S. 672 (1948). But, in several instances, failure to exhaust a state remedy or writ of error was no bar to a granting of the writ or consideration of the questions raised on the merits. Ashe v. United States ex rel. Valott, 270 U.S. 424 (1926); Matter of Moran, 203 U.S. 96 (1906); Rogers v. Peck, 199 U.S. 425 (1905); Minnesota v. Barber, 136 U.S. 313 (1890); cf. Ex parte Hull, 312 U.S. 546 (1941). In Mooney v. Holohan, 294 U.S. 103, 115 (1935), it was said that the exhaustion requirement extended "to whatever judicial remedy afforded by the State may still remain open"; and it was indicated in Woods v. Nierstheimer, 328 U.S. 211, 217 (1946), and held in United States ex rel. Rooney v. Ragen, 158 F. 2d 346, 352 (C.A. 7th, 1946), cert. denied, 331 U.S. 842 (1947), that if no state relief is available by means of a state remedial route which petitioner had apparently allowed to lapse, and the petitioner claimed he was imprisoned in violation of the Constitution of the United States, "the federal courts would be available to provide a remedy to correct such wrongs." The fear that allowing federal habeas corpus where no state appeal is taken will encourage by-passing such appeal, is unreal, since the limited scope of habeas corpus review, as compared with an appeal, will effectively deter convicted defendants from foregoing an appeal and proceeding by habeas corpus. See Exhaustion of States Remedies as a Condition for Federal Habeas Corpus, op. cit. supra this note, at 659; Habeas Corpus Exhaustion of Alternative Remedies, 40 Col. L. Rev. 535, 539 (1940); 97 U. of Pa. L. Rev. 285, 287 (1948), noting United States ex rel. Sutton v. Mulcahy, 189 F. 2d 464 (C.A. 6th, 1951).

${ }^{52} \mathrm{McGraw}$ and Stewart, op. cit. supra note 25, at 496; Certiorari and Habeas Corpus: The Comity Comedy, 46 Ill. L. Rev. 478, 480-81 (1951); The Judicial Obstacle Course, $29 \mathrm{Neb}$. L. Bull. 445 (1950); Habeas Corpus-A Method of Federal Review of State Decisions?, 26 N.C. L. Rev. 217 , 220-21 (1948).

s3 339 U.S. 200 (1950). 
the state remedies required to be exhausted before federal habeas corpus can issue; and earlier, in Ex parte Eawk, ${ }^{54}$ the Court said that the denial of certiorari, where the judgment is on the merits, is entitled to great if not decisive weight upon an application for federal habeas corpus. ${ }^{55}$ To these complementary impediments to federal habeas corpus, Chief Judge Parker of the Court of Appeals for the Fourth Circuit and of the Judicial Conference of Senior Circuit Court Judges which drafted $\S 2254$, would add the proposition that to exhaust state remedies the prisoner must reinvoke state remedies once sought by and denied to him so long as jurisdiction to grant such relief exists. ${ }^{56}$ If followed, this proposition would go far to warrant Judge Parker's observation concerning \$2254 that, "in the case of state prisoners, resort to the lower federal courts is practically eliminated where an adequate remedy is provided by state law."157 The state which accepts the suggestion implicit in the foregoing and adopts a postconviction corrective system comparable in its essentials to the federal habeas corpus legislation may, if Judge Parker's views should prevail, thereby effectively foreclose review by any federal court other than the United States Supreme Court. ${ }^{58}$

These exclusionary rules-exclusionary of federal habeas corpus reliefhave not, however, to date wholly achieved their purpose. Because of the understandable confusion in the interpretation and application of the exclusionary

54321 U.S. 114 (1944).

${ }^{55}$ See also White v. Ragen, 324 U.S. 760, 765 (1945); House v. Mayo, 324 U.S. 42,48 (1945); Habeas Corpus-A Method of Federal Review of State Decisions?, op. cit. supra note 52 , at 218 .

${ }^{56}$ Parker, op. cit. supra note 3 , at 176. See also Criminal Process and Habeas Corpus: A Remedy in the Federal Courts, 26 Ind. L.J. 552, 553 (1951); Exhaustion of State Remedies as a Condition for Federal Habeas Corpus, op. cit. supra note 51, at 667. For a contrary holding, see Ekberg v. McGee, 191 F. 2d 625 (C.A. 9th, 1951), cert. granted, 342 U.S. 952 (1951), vacated as moot, 343 U.S. 970 (1951). Compare also that branch of Wade v. Mayo, 334 U.S. 672 (1948), not disturbed by Darr v. Burford, 339 U.S. 200 (1950), which held that the exhaustion of any one of alternative state remedies satisfies the exhaustment requirement. Accord: United States ex rel. Master v. Baldi, 198 F. 2d 113 (C.A. 3d, 1952); United States ex rel. Morrison v. Foster, 175 F. 2d 495 (C.A. 2d, 1949); Pennsylvania ex rel. Hillman v. Burke, 170 F. 2d 413 (C.A. 3d, 1948); United States ex rel. Marelia v. Burke, 101 F. Supp. 615 (D.C. Pa., 1951).

57 Parker, op. cit. supra note 3 , at 174 . See also Moore, op. cit. supra note 8 , at 425,446 ; Lynch, Review of State Court Proceedings by the Federal Courts on Petitions for Writ of Habeas Corpus, 25 Temp. L.Q. 351, 354-57 (1952); McGraw and Stewart, op. cit. supra note 25, at 496; Certiorari and Habeas Corpus, op. cit. supra note 52, at 483. It is interesting to compare the Report of Judicial Conference of Senior Circuit Judges 23 (1943) with the Report of Judicial Conference of Senior Circuit Judges 18 (1947) and with 28 U.S.C.A. \& 2254 (1950). The statute proposed in the earlier report would, as compared with that later proposed and adopted, have deprived the federal courts of habeas corpus jurisdiction where state remedies had not been exhausted.

B8 Typical state legislation calculated to retain post-conviction proceedings in the state courts is that of Illinois and North Carolina. Ill. Rev. Stat. (1951) c. 38, $\$ 826-32$; N.C. Gen. Stat. Ann. (Supp., 1951) c. 15, Art. 22, \$§ 15-217 through 15-222. See Quick v. Anderson, 194 F. 2d 183 (C.A. 4th, 1951). 
rules, ${ }^{59}$ because of the serious criticisms of those rules, ${ }^{60}$ and because of the impelling drive in some courts to subordinate considerations of comity between federal and state judiciaries to substantial civil rights of state prisoners, ${ }^{61}$ federal habeas corpus still affords hope to the state prisoner convicted by process in violation of constitutional safeguards provided by the Fourteenth Amendment.

Thus, the language of the Supreme Court in many non-habeas corpus decisions advising and readvising the bar that the denial of certiorari imports no holding ${ }^{62}$ has induced some of the circuits in habeas corpus cases to accord such denial little or no weight. ${ }^{63}$ Moreover, since certiorari is denied if the state court judgment is supported upon grounds not involving federal questions ${ }^{64}$ and since few state cases raise pristine federal questions unaffected by sufficient nonfederal grounds, it is frequently difficult to determine how, as a practical matter, a lower federal court in a habeas corpus proceeding can intelligently assess a prior denial of certiorari by the United States Supreme Court where the judgment under review is that of a state court. The Supreme Court has held that where the state court action is based on state grounds, certiorari need not be sought as a condition for federal habeas corpus, and that if sought and denied, such denial does not affect a subsequent application for habeas

59 For the divergent views of the circuits prior to Darr v. Burford, 339 U.S. 200 (1950), concerning the necessity to petition for writ of certiorari as a condition to federal habeas corpus, see Habeas Corpus in the Federal Courts and the Exhaustion of Available Remedies, 50 Col. L. Rev. 856, $857 \mathrm{n} .11$ (1950). For the conflicting views of the circuits after Darr v. Burford concerning the weight to be accorded a denial of certiorari in a subsequent habeas corpus proceeding, see Certiorari and Habeas Corpus, op. cit. supra note 52, at 483-88; Habeas Corpus in the Federal Courts and the Exhaustion of Available Remedies, op. cit. supra this note, at 858 n. 22, 26 (1950).

${ }^{\circ 0}$ See, e.g., Moore, op. cit. supra note 8, at 425, 446; Certiorari and Habeas Corpus, op. cit. supra note 52, at 483-85; Criminal Process and Habeas Corpus, op. cit. supra note 56, at 554-58.

61 E.g., United States ex rel. Auld v. New Jersey, 187 F. $2 d 615$ (C.A. 3d, 1951); Bacom v. Sullivan, 194 F. 2d 166 (C.A. 5th, 1952), cert. denied, 338 U.S. 835 (1952); Jones v. Kentucky, 97 F. 2d 335 (C.A. 6th, 1938); Potter v. Dowd, 146 F. 2d 244 (C.A. 7th, 1944); Spence v. Dowd, 145 F. 451 (C.A. 7th, 1944); Fouquette v. Barnard, 198 F. 2d 96 (C.A. 9th, 1952); Ekberg v. McGee, 194 F. 2d 178 (C.A. 9th, 1952); Thomas v. Duffy, 191 F. 2d 360 (C.A. 9th, 1951). See Morgan v. Horrall, 175 F. 2d 404, 407 (C.A. 9th, 1949), cert. denied, 338 U.S. 827 (1952); Guy v. Utecht, 144 F. 2d 913, 916 (C.A. 8th, 1944); Mason v. Webb, 142 F. 2d 584, 587 (C.A. 9th, 1944), cert. denied, 323 U.S. 747 (1944).

62 Agoston v. Pennsylvania, 340 U.S. 844 (1950); Maryland v. Baltimore Radio Show, 338 U.S. 912 (1950); Sunal v. Large, 332 U.S. 174 (1947); United Stater v. Carver, 260 U.S. 482,490 (1923).

${ }^{63}$ Coggins v. O'Brien, 188 F. 2d 130 (C.A. 1st, 1951), cert. denied, 338 U.S. 881 (1952), United States ex rel. Smith v. Baldi, 192 F. 2d 540 (C.A. 3d, 1951), cert. granted, 343 U.S, 903 (1952), reargument ordered, 343 U.S. 973 (1952); United States ex rel. Master v. Baldi. 198 F. 2d 113 (C.A. 3d, 1952); Bacom v. Sullivan, 194 F. 2d 166 (C.A. 5th, 1952), cert. denied; 338 U.S. 835 (1952); Goodman v. Lainson, 182 F. 2d 814 (C.A. 8th, 1950); Anderson v. Eidson, 191 F. 2d 989 (C.A. 8th, 1951); Eckberg v. McGee, 194 F. 2 d 178 (C.A. 9th, 1952).

64 Hammond v. Superior Court, 340 U.S. 622 (1952); W.O.W. v. Johnson, 326 U.S. 120 (1945); Herb v. Pitcairn, 324 U.S. 117 (1945); Williams v. Oliver, 53 How. (U.S.) 111 (1851). 
corpus. ${ }^{65}$ Accordingly, a general denial of certiorari ${ }^{66}$ without a statement of the reasons therefor, where state grounds may exist to support the conviction supplies a very tenuous basis for denial of relief in a subsequent federal habeas corpus action. If the individual views of the Justices in Darr v. Burford be appraised and enumerated it will be seen that a majority of the Court is inclined to treat a prior general denial of certiorari as considerably less than decisive of a later application for federal habeas corpus. ${ }^{67}$

But if a denial of certiorari is negative and of little or no future consequence, the question remains: why should it be necessary in order to exhaust state court remedies to petition the Supreme Court of the United States for a writ of certiorari? In Wade v. Mayo, ${ }^{68}$ the Supreme Court said that it was not and two years later, in Darr v. Burford, the Court said that it was. ${ }^{69}$ Such reversal of position by the Court has, of course, invited extensive comment in the journals of the profession, most of it highly critical. ${ }^{70}$

Mr. Justice Reed, the principal proponent of the rule in Darr v. Burford, founds his position on the desire to assure that the Supreme Court, rather than a lower federal court, would have "first crack" at reviewing and reversing the state judgment, thereby avoiding, or at least minimizing, the prospect of a single federal district judge overruling the action of the highest court of a state. ${ }^{71}$ But experience should have dissipated any fear that permitting federal district courts to entertain habeas corpus petitions of state prisoners will often result in a single federal judge upsetting the judgment of a state court. ${ }^{72}$ For the fiscal

${ }^{65}$ Wade v. Mayo, 334 U.S. 672 (1948); Hawk v. Olson, 326 U.S. 271 (1945); White v. Ragen, 324 U.S. 760 (1945); House v. Mayo, 324 U.S. 42 (1945); Williams v. Kaiser, 323 U.S. 471 (1945); Ex parte Hawk, 321 U.S. 114 (1944).

${ }^{80}$ Usually, of course, denial of certiorari is without opinion. In Burke v. Georgia, 338 U.S. 941 (1950), the Court, when it denied certiorari from a state conviction, expressly commented the denial was without prejudice to a subsequent application for federal habeas corpus. Quaere whether, in the absence of such comment, prejudice to federal habeas corpus is intended by denial of certiorari; if not, why was the comment necessary?

${ }^{67}$ See United States ex rel. Smith v. Baldi, 192 F. 2d 540 (C.A. 3d, 1951), cert. granted, 343 U.S. 903 (1952), reargument ordered, 343 U.S. 973 (1952); Certiorari and Habeas Corpus, op. cit. supra note 52, at 481; Habeas Corpus in the Federal Courts and the Exhaustion of Available Remedies, op. cit. supra note 59, at 859.

${ }^{68} 334$ U.S. 672 (1948).

${ }^{69}$ For prior dicta presaging, and relied upon by, Darr v. Burford, 339 U.S. 200 (1950), see Ex parte Hawk, 321 U.S. 114, 116-17 (1944).

${ }^{70}$ Authorities cited notes 52, 59, 60 supra.

${ }^{71}$ See also Baker v. Grice, 169 U.S. 284, 291 (1898); Parker, op. cit. supra note 2, at 176. Of course, the prospect of such ignominious reversal by a lower federal court could serve to keep the state courts alert to protect federal constitutional rights. Cf. Criminal Process and Habeas Corpus, op. cit. supra note 56 , at 558.

72 Twenty-five years ago, the present Judge Dobie of the Court of Appeals for the Fifth Circuit observed that there was no danger of excessive exercise of federal habeas corpus jurisdiction and that "it is believed that federal habeas corpus in cases of state custody has done far more good than harm." Dobie, op. cit. supra note 8, at 449. 
years from 1943 to $1946,{ }^{73}$ statistics are available on the number of petitions filed by state prisoners in federal district courts, and the number of prisoners released. For the fiscal years from 1945 to 1951, the statistics show the number of federal-question habeas corpus cases disposed of by district courts and the number in which petitioners were successful. ${ }^{74}$ These are shown in Tables I and $\mathrm{II}$ :

TABLE I

\begin{tabular}{l|c|c|c}
\hline \hline & $\begin{array}{c}\text { Number of } \\
\text { petitions } \\
\text { filed by state } \\
\text { court } \\
\text { prisoners }\end{array}$ & $\begin{array}{c}\text { Number of } \\
\text { petitioners } \\
\text { released }\end{array}$ & Percent \\
\hline $1943-44 \ldots \ldots \ldots \ldots$ & 449 & 9 & 1.8 \\
$1944-45 \ldots \ldots \ldots \ldots$ & 449 & 7 & 1.4 \\
$1945-46 \ldots \ldots \ldots \ldots$ & 411 & 4 & 1.0 \\
\hline
\end{tabular}

TABLE II

\begin{tabular}{|c|c|c|c|}
\hline & $\begin{array}{c}\text { Number of } \\
\text { federal-ques- } \\
\text { tion habeas } \\
\text { corpus cases } \\
\text { disposed of } \\
\text { by district } \\
\text { courts }\end{array}$ & $\begin{array}{c}\text { Number in } \\
\text { which peti- } \\
\text { tioners were } \\
\text { successful }\end{array}$ & Percent \\
\hline $\begin{array}{l}1945-46 \ldots \ldots \ldots \ldots \\
1946-47 \ldots \ldots \ldots \ldots \\
1947-48 \ldots \ldots \ldots \\
1948-49 \ldots \ldots \ldots \\
1949-50 \ldots \ldots \ldots \\
1950-51 \ldots \ldots \ldots \ldots\end{array}$ & $\begin{array}{l}503 \\
481 \\
487 \\
610 \\
642 \\
469\end{array}$ & $\begin{array}{l}14 \\
13 \\
11 \\
10 \\
18 \\
13\end{array}$ & $\begin{array}{l}2.8 \\
2.7 \\
2.3 \\
1.6 \\
2.8 \\
2.7\end{array}$ \\
\hline
\end{tabular}

Obviously, lower federal courts are far more loathe to upset state court decisions for violations of federal constitutional rights than is the United States Supreme Court. In his dissent in Darr v. Burford, Justice Frankfurter summarized the situation this way:

Nor need we be concerned lest the federal District Courts will lightly inject themselves into the State criminal process and open wide the State prison doors. Experience completely dispels such excogitated fears. The District Courts are presided over by judges who are citizens of the States, with loyalties to it no less strong than those of the judges of the State courts. Judges often come to the federal courts from the State courts. ${ }^{75}$

${ }^{73}$ Speck, Statistics on Federal Habeas Corpus, 10 Ohio St. L.J. 337, 357 (1949).

74 Tbid.; Darr v. Burford, 339 U.S. 200, 233 n. 3 (1950); letter to authors under date of June 9, 1952, from Will Shafroth, Chief of the Division of Procedural Studies and Statistics, Administrative Office of the United States Courts.

${ }^{75} 339$ U.S. 200, 232-33 (1950). 
Regard for the status and prestige of the highest state courts, upon which the Supreme Court based its rule in Darr v. Burford, is entertained, at least to the same degree, by federal district courts and explains why district judges have and will continue to rule favorably on petitions in habeas corpus proceedings on rare occasions only. This fact of judicial life affords a sufficient safeguard against the threat of casual or cavalier treatment of state convictions in federal habeas corpus without the interposition of the requirement that certiorari must be sought in order to exhaust state remedies. The result of the rule is a waste of the time of the Supreme Court in considering needless, and one might almost add useless, petitions for certiorari, and of members of the bar in having to prepare them. ${ }^{76}$ And the requirement has tended to induce lower courts and the bar to give greater effect to denials of certiorari by the United States Supreme Court than such denials, by hypothesis, should have. If the Supreme Court insists on having the "first crack" at a case, then it is difficult to keep the bench or the bar from thinking that a denial of certiorari by the Court must have some significance as to the merits of a case.

If the rule of Darr v. Burford is, however, to persist, then it should be made clear by the Supreme Court that in the exercise of its certiorari jurisdiction, the Court is not thereby functioning as the exclusive, or even principal, federal forum for the review of federal questions raised upon state prosecutions. ${ }^{77}$ For several circuits have so construed the Supreme Court's certiorari jurisdiction in federal habeas corpus cases. ${ }^{78}$ In their view, irrespective of the nature of

${ }^{76}$ It is hardly necessary to add that the rule also adds to the time during which the incarcerated litigant must wait for federal review. The time necessary to exhaust state remedies, including certiorari from each of the various remedies, is generally so considerable that, except in serious offenses, it may be expected that the sentence will have been served before access to the federal courts is available. For an example where this consideration brought expeditious habeas corpus action, see Bacom v. Sullivan, 194 F. 2d 166 (C.A. 5th, 1952), cert. denied, 338 U.S. 835 (1952).

${ }^{77}$ Clarity on the effect of a denial of certiorari in subsequent habeas corpus proceedings is required not only by the rule in Darr v. Burford, but also because, quite apart from the necessity to petition for certiorari imposed by that case, many convicted in state courts prepared to seek review of their convictions will, as a matter of course, first seek review by certiorari and, in each such instance, it is important to know the impact of the Court's action in denying certiorari on any later habeas corpus proceeding. That the Court is troubled by this question and desires to settle it at the present term, appears from the series of cases argued at the last Term which raised the question, and which were set down for reargument for the October 1952 Term: United States ex rel. Smith v. Baldi, 192 F. 2d 540 (C.A. 3d, 1951), cert. granted, 343 U.S. 903 (1952); Speller v. Allen, 192 F. 2d 477 (C.A. 4th, 1951), cert. granted, 342 U.S. 953 (1951); Brown v. Allen, 192 F. 2d 477 (C.A. 4th, 1951), cert. granted, 343 U.S. 903 (1952). Reargument was ordered in all three cases in 343 U.S. 973 (1952).

78 This is the approach of the Fourth Circuit, which is fully set out in Sanderlin v. Smyth, 138 F. 2d 729 (C.A. 4th, 1943), and seems also to be that followed by the Second Circuit. United States ex rel. Rheim v. Foster, 175 F. 2d 772 (C.A. 2d, 1949); Schechtman v. Foster, 172 F. 2 d 339 (C.A. 2d, 1949); United States ex rel. Steele v. Jackson, 171 F. 2d 432 (C.A. 2d, 1949), cert. denied, 336 U.S. 939 (1949). The Court of Appeals for the District of Columbia appears to follow a similar view. Smith v. United States, 187 F. 2d 192 (App. D.C., 1950), cert. denied, 341 U.S. 927 (1951); Kenion v. Gill, 155 F. 2 d 176 (App. D.C., 1946). See authorities cited note 63 supra, for the views held by other circuits. 
the questions raised upon habeas corpus, so long as such questions were the subject of, or capable of, fair review in the state courts and thereafter in the United States Supreme Court in the course of a petition for a writ of certiorari, they cannot be reconsidered in the federal courts in a habeas corpus proceeding. Federal habeas corpus is thus confined to those cases where, either because of ignorance, fraud, duress, or lack of counsel, the petitioner could not at his trial, or thereafter, raise fundamental constitutional objections in the state courts, or to cases where fundamental constitutional objections derive from matter alinnde the record-such as evidence obtained after a trial that the prosecution knowingly used perjured testimony-and the state provides no adequate remedy in such circumstances. ${ }^{79}$ In the other, more usual situation, wherein the objections are raised at the state trial, there adjudicated, and afterwards reviewed, federal review beyond certiorari would be foreclosed, no matter how gross the error and no matter how basic the right deprived. But $\S 2254$, in terms, made the exhaustion of state remedies a basis for, not a bar to, federal habeas corpus. Yet the approach summarized above yields the opposite result. For by that approach, once state remedies are exhausted, assuming their adequacy, federal habeas corpus is unavailable.

A somewhat similar approach to $\S 2254$ had been developed by some of the circuits prior to the decision in Ex parte $B$ arwk. ${ }^{80}$ Those lower federal courts allowed the writ to issue only upon a showing of "extraordinary circumstances," even where state remedies had been exhausted. ${ }^{81}$ The Supreme Court, in $E x$ parte Hawk, presented, in the clearest terms, its instruction to the federal judiciary that the requirement that state remedies be exhausted before federal habeas corpus might issue is distinct from, and alternative to, the availability of federal habeas corpus where state remedies are not exhausted in the instance of "extraordinary circumstances." In view of Ex parte Hawk, it is to be re-

79 United States ex rel. Turpin v. Snyder, 183 F. 2 d 742 (C.A. 2d, 1950); Mitchell v. Youell, 130 F. 2d 880 (C.A. 4th, 1942).

${ }^{80} 321$ U.S. 114 (1944).

81 United States ex rel. Murphy v. Murphy, 108 F. 2d 861, 862 (C.A. 2d, 1940), cert. denied, 309 U.S. 661 (1940); Kelly v. Ragen, 129 F. 2d 811, 814-15 (C.A. 7th, 1942); Hawk v. Olson, 130 F. $2 d$ 910, 911, 913 (C.A. 8th, 1942); In re Anderson, 117 F. 2d 939, 940 (C.A. 9th, 1941); United States ex rel. Foley v. Ragen, 52 F. Supp. 265, 269-70 (N.D. Ill., 1943), rev'd, 143 F. 2d 774 (C.A. 7th, 1944).

82321 U.S. 114, 117-18 (1944). See also White v. Ragen, 324 U.S. 760 (1945); House v. Mayo, 324 U.S. 42 (1945); Exhaustion of State Remedies as a Condition for Federal Habeas Corpus, op. cit. supra note 51, at 655; Relief by Federal Habeas Corpus from Arkansas Conviction Challenged as Unconstitutional, 2 Ark. L. Rev. 424 n. 3 (1948). The "extraordinary circumstances" exception to the requirement that state remedies be exhausted prior to federal habeas corpus review originally seemed to contemplate those situations where exigenciesusually pertaining to the protection of some aspect of the federal government from state action-made it inadvisable to permit the state processes to run their course. Matter of Spencer, 228 U.S. 652 (1913); Pettibone v. Nichols, 203 U.S. 192 (1906); In re Lincoln, 202 U.S. 178 (1906); Boske v. Comingore, 177 U.S. 459 (1900); Ohio v. Thomas, 173 U.S. 276 (1899); In re Loney, 134 U.S. 372 (1890); Ex parte Royall, 117 U.S. 241 (1886). Later, the exception came to pertain to those very unusual cases where state processes, though adequate in form, 
called that $\$ 2254$ specifies not only that "extraordinary circumstances" and exhaustion of states remedies are alternative requirements, but also that inadequacy of state remedies, which some circuits now treat as an indispensable, conjunctive condition for federal habeas corpus jurisdiction, is an additional alternative. ${ }^{83}$

There has always been, in our federal system, some federal forum for the review of substantial federal questions raised by one in state custody. We disagree with the view that the federal function is sufficiently performed, in the ordinary situation, by the Supreme Court through the medium of certiorari jurisdiction. When the Supreme Court's jurisdiction was invocable as of right by writ of error, the conflicting interests of federal review of federal questions and respect for the state courts could be accommodated by stringently delimiting such review by habeas corpus in the lower federal courts and largely confining the power to review and reverse to the Supreme Court. ${ }^{84}$ No such accommodation is possible now, when the Court's jurisdiction is by writ of certiorari and, therefore, discretionary. At best, those conflicting interests can now be accommodated by giving the Court the "first crack" at reviewing and reversing, as was required in Darr v. Burford, and, if the Court declines, by allowing the petitioner to obtain review by federal habeas corpus. The Court's certiorari jurisdiction cannot be extended to provide the principal federal forum for the review of federal questions. For, admittedly, certiorari jurisdiction is exercised on factors and conditions which, in considerable measure, are unrelated to the merits of the cause under review. ${ }^{85} \mathrm{If}$ in passing on certiorari applications, the Court is thereby functioning-as it did on writs of error-as the first and last forum of federal review of important federal questions raised by persons held in state custody, then responsibility would dictate consideration of those applications upon bases and criteria characteristic of writ of error jurisdiction-the very result it was intended to eliminate when, at the behest of the Supreme Court, the Acts of 1916 and 1925 were adopted. ${ }^{86}$

In the light of its certiorari jurisdiction, the Supreme Court is not a sufficient federal forum for the review of fundamental questions raised by persons in state

were, in fact, inadequate. Moore v. Dempsey, 261 U.S. 86 (1923); Downer v. Dunaway, 53 F. 2d 586 (C.A. 5th, 1931). Today, the exception has no definable scope and may extend to almost any instances where any one of the innumerable technical bars to federal habeas corpus stands in the way of a court's desire to render what seems to it to be patent and urgently required justice. Collins v. Frisbie, 342 U.S. 519 (1952); Eckberg v. McGee, 194 F. 2d 178 (C.A. 9th, 1952); Bacom v. Sullivan, 194 F. 2d 166 (C.A. 5th, 1952), cert. denied, 338 U.S. 835 (1952); Thomas v. Duffy, 191 F. 2d 360 (C.A. 9th, 1951); United States ex rel. Auld v. New Jersey, 187 F. 2d 615 (C.A. 3d, 1951); Spence v. Dowd, 145 F. 2d 451 (C.A. 7th, 1944).

${ }^{83}$ Exhaustion of State Remedies as a Condition for Federal Habeas Corpus, op. cit. supra note 51, at 664 .

${ }^{84}$ See cases cited note 20 supra.

${ }^{85}$ Maryland v. Baltimore Radio Show, 338 U.S. 912 (1950).

${ }^{88} \mathrm{Cf}$. Certiorari and Habeas Corpus, op. cit. supra note 52, at 485. 
custody. That regard for the state courts which would seek, as far as possible, to authorize only the Supreme Courts to reverse the action of the highest court of the state is now adequately expressed by the requirement of Darr v. Burford that certiorari must be sought before the institution of a habeas corpus proceeding. At the same time, the regard owing to those who complain that they have been deprived of their liberty in violation of fundamental federal mandates and prohibitions entitles such persons, once the Court has declined to review the state action complained of, to obtain that federal review of such objections which has traditionally inhered in our federal system; and for the individual in such circumstances, federal habeas corpus is the necessary and appropriate remedy.

\section{POSTSCRIPT}

After the foregoing discussion was in galley the United States Supreme Court, on February 9, 1953, handed down its decisions on a series of cases $^{87}$ with the "hope" that

the conclusions reached herein will result in the improvement of the administration of justice and leave the indispensable function of the Great Writ unimpaired in usefulness. ${ }^{88}$

In fulfilment of that "hope," certain propositions previously beclouded by uncertainty have now been definitely settled.

It is now established as the position of the majority of the Court that a denial of certiorari by the United States Supreme Court shall have no effect in any subsequent federal habeas corpus proceeding. ${ }^{89}$ Here Mr. Justice Frankfurter has persuaded a majority of the Court by an elaborate factual and policy demonstration that the difficulty in perceiving or assigning the reasons for a denial of certiorari are so great as to preclude attributing to such denial any effect in a subsequent proceeding. Mr. Justice Reed, speaking for a minority of the Court on this matter, now only dissents to the point that he would insist that, where the record which was before the Supreme Court when it denied certiorari presented cleanly a "disentangled" federal question, then the District Judge should be allowed in his discretion to accord weight to the denial of certiorari.

Also now settled is the proposition that once the petitioner for habeas corpus has exhausted one route of state remedies, he cannot be required to exhaust every other state route as a prerequisite to federal habeas corpus relief. In its determination of this question the Court appeared unanimous; the powerful

${ }^{27}$ Brown v. Allen, Speller v. Allen, Daniels v. Allen, 73 S. Ct. 397 (U.S., 1953) (hereinafter referred to as Daniels v. Allen); United States ex rel. Smith v. Baldi, 73 S. Ct. 391 (U.S., 1953).

88 Daniels v. Allen, 73 S. Ct. 397, 405 (U.S., 1953).

${ }^{89}$ Notwithstanding this rule, the Court affirmed the dismissal of the petitions for habeas corpus in these cases under review although the District Court and the Court of Appeals for the Fourth Circuit "erroneously gave consideration to our denial of certiorari." Tbid., at 408. 'This conclusion was reached because the District Judge had allegedly also based his decision on the evidence before him independent of the action of the Supreme Court in denying certiorari. 
judicial authority to the contrary was Judge Parker, Chief Judge of the Fourth Circuit Court of Appeals and Chairman of the Judicial Conference Committee which drafted the current federal habeas corpus statutory provisions, whose views have hereinabove been set forth. ${ }^{90}$

And while the Court did not expressly direct itself to the question whether exclusion of Negroes from juries, the introduction into evidence of coerced confessions, and other procedural defects violative of the due process and equal protection clauses of the Fourteenth Amendment are appropriate for review in federal habeas corpus, the Court impliedly decided this question in the affirmative. For each such contention was considered on the merits in the cases just decided wherever it was found that the contention had been properly raised, presented and prosecuted through the available state remedies. ${ }^{91}$

Less clearly settled by the Court was the problem of how far the state proceedings and adjudication resulting in the judgment of conviction challenged in the federal court are conclusive in the federal proceedings. Of course, by hypothesis, such state proceedings and judgment cannot be wholly conclusive for otherwise the remedy of federal habeas corpus would be meaningless. Mr. Justice Reed, whose opinion on this question is characterized as "that of the Court" ${ }^{\prime 92}$ said:

[W] here the state action was based on an adequate state ground, no further examination is required, unless no state remedy for the deprivation of federal constitutional rights ever existed. ... Furthermore, where there is material conflict of fact in the transcripts of evidence as to deprivation of constitutional rights, the District Court may properly depend upon the state's resolution of the issue. ... In other circumstances the state adjudication carries the weight that federal practice gives to the conclusion of a court of last resort of another jurisdiction on federal constitutional issues. It is not res judicata. ${ }^{93}$

And with respect to the right of a state prisoner to a hearing on the law or the facts before a federal court, Mr. Justice Reed said:

Applications to district courts on grounds determined adversely to the applicant by state courts should follow the same principle-a refusal of the writ without more, if the court is satisfied, by the record, that the state process has given fair consideration to the issues and the offered evidence, and has resulted in a satisfactory conclusion. Where the record of the application affords an adequate opportunity to weigh the sufficiency of the allegations and the evidence, and no unusual circum-

${ }^{90}$ See page 518 supra.

${ }^{91}$ In Daniels v. Allen, the Court held that the failure to perfect an appeal in the manner and time required by North Carolina law was a failure to exhaust state remedies and was, consequently, a bar to review habeas corpus, Frankfurter, Douglas, and Black, JJ. dissenting. See note 89 supra. In this connection, the Court also held that the failure to exhaust an appeal from a conviction was no bar to federal habeas corpus even if the state provided some other remedy to test the validity of the conviction and that remedy was exhausted. See also Wade v. Mayo, 334 U.S. 672 (1948), and other authorities cited at note 51 supra.

92 Daniels v. Allen, 73 S. Ct. 397, 405 (U.S., 1953).

${ }^{98}$ Ibid., at 408 . 
stances calling for a hearing are presented, a repetition of the trial is not required. . . . However, a trial may be had in the discretion of the federal court or judge hearing the new application. A way is left open to redress violations of the Constitution.... Although they have the power, it is not necessary for federal courts to hold hearings on the merits, facts or law a second time when satisfied that federal constitutional rights have been protected. It is necessary to exercise jurisdiction to the extent of determining by examination of the record whether or not a hearing would serve the ends of justice. ${ }^{94}$

Mr. Justice Frankfurter, whose separate opinion on the bearing of the proceedings in the state courts in federal habeas corpus "is designed to make explicit and detailed matters that are also the concern of Mr. Justice Reed's opinion," should be held and the effect to be accorded the action in the state courts. Thus he would allow a hearing, in the discretion of the District Judge

[i]f the issues are simple, or if the record is called for and is found inadequate to show how the State court decided the relevant historical facts. . . .96

And he accords somewhat less conclusive weight to the conclusions reached in the state proceedings:

Unless a vital flaw be found in the process of ascertaining . . f facts in the State court, the District Judge may accept their determination in the State proceeding and deny the application. On the other hand, State adjudication of questions of law cannot, under the habeas corpus statute, be accepted as binding. It is precisely these questions that the federal judge is commanded to decide. ... Where the ascertainment of the historical facts does not dispose of the claim but calls for interpretation of the legal significance of such facts ... the District Judge must exercise his own judgment on this blend of facts and their legal values. Thus, so-called mixed questions or the application of constitutional principles to the facts as found leave the duty of adjudication with the federal judge. ${ }^{97}$

It was the thesis of this article that one complaining of the deprivation of fundamental federal constitutional rights has been and should be entitled to at least one review of that contention in a federal forum. Assurance of such review was, as we have shown, denied by any rule that when the Supreme Court of the United States refused certiorari further federal review by habeas corpus was foreclosed. Any such rule is now rejected. However, the protagonists of that rule now appear to urge that the state determination, unless marked by unremediable procedural deficiency, is final in any subsequent federal habeas corpus proceeding. That this position is, in its effect, little different from that according finality to a denial of certiorari is made explicit by Mr. Justice Reed:

94 Ibid., at 410-11. In the case of Brown v. Allen, Mr. Justice Reed, on the basis of the quoted delineation of the scope of a hearing on federal habeas corpus, held that matter raised for the first time on federal habeas corpus which was previously available to the petitioner was "not open to consideration."

95 Daniels v. Allen, 73 S. Ct. 437, 441 (U.S., 1953).

96 Ibid., at 444.

${ }^{97}$ Ibid., at 446. 
We think it inconsistent to allow a district court to dismiss an application on its appraisal of the state trial record, as we understand those do who oppose our suggestion ... but to refuse to permit the district court to consider relevant our denial of certiorari. ${ }^{98}$

Accordingly, the division among the members of the Court concerning the effect of a denial of certiorari may now become division on a new issue, i.e., the effect to be accorded the state action.

At this time it cannot be determined whether the view of Mr. Justice Reed or that of $\mathrm{Mr}$. Justice Frankfurter as to the effect to be accorded state proceedings and judgment enlists a majority of the Court. As the majority opinion written by $\mathrm{Mr}$. Justice Reed closely analyzed the issues of fact raised and passed upon in the state courts, the cases decided did not sharply pose for the Court the question of the precise effect to be accorded state determinations. That question will more likely arise when a federal court in habeas corpus reaches a different conclusion on a given set of facts from that previously reached by a state court. When such a situation arises, the Court will be confronted with the basic controversy which inheres in the definition of the proper purpose and function of federal habeas corpus.

s8 Ibid., at 407. 